FALCONER, D. S. (1989): Introduction to Quantitative Genetics. John Wiley and Sons, New York.

Fox, C. W. (2005): Problems in measuring among-family variation in inbreeding depression. American Journal of Botany 92: 1929-1932.

Frankel, R. and E. Galun (1977): Pollination Mechanisms, Reproduction and Plant Breeding. Springer-Verlag, Berlin, Heidelberg, New York.

GEIGER, H. H. (1982): Breeding methods in diploid rye (Secale L.) Tag. Ber. Akad. Landwirtsch. Wiss. DDR 198: 305-332.

Gerber, S., M. Chabrier and A. Kremer (2003): FaMoz: a software for parentage analysis using dominant, codominant and uniparentally inherited markers. Mol. Ecol. Notes 3: 479-481.

Goodman, D. (1987): The demography of chance extinction, pp. 11-34. In: Viable Populations for Conservation, edited by M. E. SoulÉ, Cambridge University Press, Cambridge, UK.

HeINZE, B. and F. LEFÉvRe (1999): In situ restoration genetics of riparian populations of $P$. nigra, pp. 43-50. In: Populus nigra Network, edited by J. TUROK et al., IPGRI, Rome, Italy.

KelleR, L. F. and D. M. WAlleR (2002): Inbreeding effects in wild populations. Trends in Ecology and Evolution 17(5): 230-241.

LANDE, R. D. and W. Schemske (1985): The evolution of self fertilization and inbreeding depression in plants. I. Genetic models, Evolution 39, 24-40.

LYNCH, M. and B. WALSH (1998): Genetics and Analysis of Quantitative Traits. Sinauer, Sunderland/MA.
Pemberton, J. (2004): Measuring inbreeding depression in the wild: the old ways are the best. Trends in Ecology and Evolution 19: 613-615.

PospíšKovÁ, M. and I. ŠÁLKOvÁ (2006): Population structure and parentage analysis of black poplar along the morava River. Canadian Journal of forest Research 36: 1067-1076.

Smulders, M. J. M., J. VAN DER Schoot, P. AREns and B. Vosman (2001): Trinucleotide repeat microsatellite markers for black poplar (Populus nigra L.). Molecular Ecology Notes 1: 188-190.

TABbener, H. E. and J. E. Cottrell (2003): The use of PCR based DNA markers to study the paternity of poplar seedlings. For. Ecol. Manage. 179: 363-376.

Vanden Broeck, A., V. Storme, J. E. Cottrell, W. Boeruan, E. Van Bockstaele, P. Quataert and J. Van SLYCKEN (2004): Gene flow between cultivated poplars and native black poplar (Populus nigra L.): a case study along the river Meuse on the Dutch-Belgian border. For. Ecol. Manage. 197: 307-310.

van DER Schoot, J., M. Pospís̆Ková, B. Vosman and M. J. M. SMULDERS (2000): Development and characterization of microsatellite markers in black poplar (Populus nigra L.). Theor. Appl. Genet. 101: 317-322.

WeBer, E. (1978): Mathematische Grundlagen der Genetik. VEB Gustav Fischer Verlag Jena.

WRIGHT, S. (1922): Coefficients of inbreeding and relationship. American Nature 56: 330-339.

WRIGHT, S. (1977): Experimental Results and Evolutionary Deductions, Evolution and the Genetics of Populations, vol. 3. University of Chicago Press, Chicago.

\title{
Short Note: The Genetic Correlation Between Air-dried Density and Basic Density in Eucalyptus Nitens Wood Cores
}

\author{
By M. G. HAmilton ${ }^{\left.1),{ }^{*}\right)}$, C. A. Raymond ${ }^{2)}$ and B. M. Potts ${ }^{1)}$
}

(Received $5^{\text {th }}$ February 2007)

\begin{abstract}
Cores extracted from trees to assess wood chemistry are generally not used to assess basic density in eucalypt pulpwood breeding programmes, as the measurement of basic density requires high temperature drying. However, both wood chemistry and air-dried density can be assessed on the same core. This study found that the inter-trait genetic correlation between core air-dried and basic density to be effectively equal to one in two Tasmanian Eucalyptus nitens progeny trials. This implies

\footnotetext{
1) School of Plant Science and Cooperative Research Centre for Forestry, University of Tasmania, Private Bag 55, Hobart, Tasmania, 7001 Australia.

2) School of Environmental Science and Management, Southern Cross University, PO Box 157, Lismore, NSW, 2480 Australia.

*) Corresponding author. Email: matthew.hamilton@utas.edu.au. Phone: +61 3 62262603, Fax: +61362262698
}

that selection for basic density could be undertaken using air-dried density with little or no reduction in genetic gain, thus negating the need to extract a separate core to assess basic density and wood chemistry. The adoption of this practice could considerably reduce the cost of assessing these traits in eucalypt breeding programmes.

Key words: Eucalyptus nitens, selection trait, non-destructive assessment, air-dried density, basic density, wood chemistry, pulp yield, cellulose content, near infrared spectroscopy (NIR), genetic correlation.

\section{Introduction}

Eucalypt pulpwood breeders routinely select trees according to diameter at breast height and wood core basic density (i.e. oven-dry weight divided by green volume; TAPPI, 1989). Furthermore, near infrared 
reflectance spectroscopy (NIR) is increasingly utilised as a cheap and non-destructive means of selecting trees according to wood chemistry (e.g. cellulose content, pulp yield, lignin content and/or extractive content; RAYMOND et al., 2001; POKE and RAYMOND, 2006).

Assessment of basic density requires cores to be ovendried at approximately $105^{\circ} \mathrm{C}$ (TAPPI, 1989). Conversely, cores extracted for chemical analysis are dried at low temperature to prevent significant alteration of wood chemistry (e.g. below $35^{\circ} \mathrm{C}$; AS/NZS 1301.002s 2004). Accordingly, the measurement of both core basic density and wood chemistry has historically required the extraction of multiple cores from each tree (e.g. RAYMOND and SCHIMLECK, 2002). However, if trees from breeding populations could be efficiently selected for high basic density on the basis of the air-dried density (i.e. air-dried weight divided by green volume) of cores extracted for the assessment of wood chemistry, the total cost of assessing these traits in eucalypt breeding programmes could be substantially reduced. The principal aim of this study was to investigate the feasibility of this approach by examining the strength of the genetic correlation between air-dried and basic density in $E$. nitens.

\section{Materials and Methods}

This study was undertaken on a sub-sample of trees growing in two first-generation open-pollinated $E$. nitens

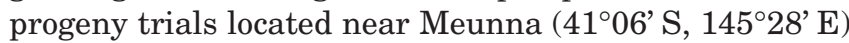
and Tarraleah $\left(42^{\circ} 20^{\prime} \mathrm{S}, 146^{\circ} 27^{\prime} \mathrm{E}\right)$ in Tasmania, Australia (for details see DuTKOwski et al., 2001). The trials were incomplete block designs comprising five replicates of 21 incomplete blocks, each containing 20 five-tree row-plots of open-pollinated families. The trials included families from all three of the races proposed by DuTKOwsKI et al. (2001). These races were defined based on geographic patterns of quantitative genetic variation in the central Victorian population of $E$. nitens. The Meunna trial was pruned and thinned to two large trees per plot six years after planting.

Nine years after planting, 12-mm bark-to-bark wood cores were extracted $0.9 \mathrm{~m}$ from the base of trees from 12, 36 and 56 selected families in the Connor's Plain, Northern and Southern races respectively. Where possible, four families were randomly selected for coring from each locality from which seed was collected (refer to DUTKOWski et al., 2001) so as to include families from a broad geographic range within each race. The majority (102) of the sampled families were common to both trials. Within each family, three to six (usually four) healthy unforked trees were selected for coring so as to include stems from multiple replicates and a broad range of diameters (all greater than $9.5 \mathrm{~cm}$ at $1.3 \mathrm{~m}$ ).

Green volumes were measured (TAPPI, 1989) before cores were loosely stacked in trays and air-dried in a laboratory to equilibrium moisture content (mean $8.78 \%$, std. dev. $0.68 \%$ ). The cores were then weighed and their air-dried densities determined. Finally, cores were oven-dried at $105^{\circ} \mathrm{C}$ for 24 hours, weighed and their basic densities calculated.

Bivariate mixed model analyses were conducted separately for each trial using ASREML (GILMOUR et al., 2002 ) by fitting the following model, in matrix notation:

$$
y=X_{1} b+X_{2} r+Z_{1} f+e
$$

where $y$ is a vector of phenotypic observations for airdried and basic density, $b$ is a vector of the fixed replicate effects, $r$ is a vector of the fixed race effects, $f$ is a vector of the random family within race effects, $e$ is a vector of residuals for both traits, and $X_{1}, X_{2}$ and $Z_{1}$ are incident matrices relating the phenotypic observations to the effects in the model. Incomplete block effects were not fitted in the model, as incomplete block variance estimates were found to be very low and not significantly different to zero in preliminary analyses. For each trial, an estimate of the inter-trait family correlation (i.e. the additive genetic correlation) between air-dried and basic density was derived from family (co)variance components estimated using a restricted maximum likelihood (REML) procedure (GILMOUR et al., 2002). Withinrace narrow-sense heritabilities $\left(h_{o p}^{2}\right)$ for each trait and site were calculated from variance components estimated using equivalent univariate models and assuming a coefficient of relationship within open-pollinated families of 0.4 to account for an assumed selfing rate of $30 \%$ (GRIFFIN and COTTERILL, 1988). Within-site inter-trait Pearson's phenotypic correlation coefficients were estimated using the CORR procedure in SAS ${ }^{\mathrm{TM}}$ (SAS INSTITUTE INC., 2002).

\section{Results and Discussion}

Estimates of the inter-trait genetic correlation between air-dried and basic density were effectively equal to one at both sites (Table 1). This implies that selection for whole-tree basic density could be undertaken using core air-dried density instead of core basic density with little or no reduction in genetic gain. Furthermore, given that air-dried density and wood chemistry can be measured on the same core and assuming that

Table 1. - Means, heritabilities and intertrait correlation coefficients for core air-dried and basic density by trial site. Standard errors are in parentheses.

\begin{tabular}{llcccc}
\hline Trial & $\begin{array}{l}\text { Measure of } \\
\text { density }\end{array}$ & $\begin{array}{c}\text { Least squares } \\
\text { mean } \\
\left(\mathrm{kg} \mathrm{m}^{-3}\right)\end{array}$ & $\begin{array}{c}\text { Narrow-sense } \\
\text { heritability }\end{array}$ & $\begin{array}{c}\text { Intertrait } \\
\text { genetic } \\
\text { correlation }\end{array}$ & $\begin{array}{c}\text { Intertrait } \\
\text { phenotypic } \\
\text { correlation }\end{array}$ \\
\hline Tarraleah & Basic & $449(2)$ & $0.423(0.117)$ & $1.001(0.001)$ & $0.997(0.003)$ \\
& Air-dried & $488(2)$ & $0.420(0.117)$ & & \\
Meunna & Basic & $404(2)$ & $0.378(0.113)$ & $1.000(0.001)$ & $0.996(0.004)$ \\
& Air-dried & $440(2)$ & $0.381(0.113)$ & & \\
\hline
\end{tabular}


both of these core traits exhibit a strong genetic correlation with relevant whole-tree traits (i.e. objective traits; refer to RAYMOND et al., 2001), these findings suggest that only one core needs to be extracted from trees to assess both density and wood chemistry in eucalypt breeding programmes. The adoption of this practice, combined with the use of solid wood rather than ground samples to measure NIR spectra (POKE and RAYMOND, 2006), could considerably reduce the cost of assessing wood properties in eucalypt pulpwood breeding programmes.

\section{Acknowledgements}

We thank LindA BALLARD, CHRIS HARWOOD, LEON SAVAGE, Forestry Tasmania, Norske Skog Ltd., the CRC for Sustainable Production Forestry, the Australian Research Council (Linkage grant LP0453704) and Ensis.

\section{References}

AS/NZS 1301.002s (2004): Methods of test for pulp and paper. Method 002s: Preparation of wood samples for chemical analysis. Joint publication of Standards Australia, Homebush, NSW and Standards New Zealand, Wellington, NZ.

Dutkowski, G. W., B. M. Potts, D. R. Williams, P. D. KuBE and C. MCARThur (2001): Geographic genetic variation in central Victorian Eucalyptus nitens in
IUFRO Symposium on Developing the Eucalypt for the Future, CD-Rom communication, Valdivia, Chile. 10-15 September. Instituto Forestal.

Gilmour, A. R., B. J. Gogel, B. R. Cullis, S. J. Welham, and R. Thompson (2002): ASReml User Guide Release 1.0. VSN International Ltd, Hemel Hempstead, UK.

GRIFFIN, A. R. and P. P. CotTERILL (1988): Genetic variation in growth of outcrossed, selfed and open-pollinated progenies of Eucalyptus regnans and some implications for breeding strategy. Silvae Genetica 37: 124-131.

Poke, F. S. and C. A. RAYMOND (2006): Predicting extractives, lignin, and cellulose contents using near infrared spectroscopy on solid wood in Eucalyptus globulus. Journal of Wood Chemistry and Technology 26: 187-199.

Raymond, C. A., L. R. Schimleck, A. Muneri and A. J. MiCHELL (2001): Nondestructive sampling of Eucalyptus globulus and $E$. nitens for wood properties. III. Predicted pulp yield using near infrared reflectance analysis. Wood Science and Technology 35: 203-215.

RAYMond, C. A. and L. R. Schimleck (2002): Development of near infrared reflectance analysis calibrations for estimating genetic parameters for cellulose content in Eucalyptus globulus. Canadian Journal of Forest Research 32: 170-176.

SAS InstituTE INC. (2002): The SAS system for Windows, Version 9.1.

TAPPI (1989): Basic density and moisture content of pulpwood. no. T258 om-98, Technical Association of the Pulp and Paper Industries (TAPPI).

\title{
Heterogeneity and Spatial Autocorrelation for Chloroplast Haplotypes in Three Old Growth Populations of Northern Red Oak
}

\author{
By Y. FenG ${ }^{1)}$, W. Sun ${ }^{2)}$ and J. Romero-Severson ${ }^{1), *)}$
}

(Received $9^{\text {th }}$ February 2007)

\begin{abstract}
In eastern North America, evidence for cryptic northern refugia could contribute to resolving Reid's Paradox, the disparity between the rate of oak recolonization indicated by pollen deposition and the rate indicated by contemporary seed dispersal studies. Severe anthropogenic disturbance of oak-dominated forests throughout eastern North America followed by regeneration from isolated patches and deliberate planting in some regions could obscure the signal of discontinuity expected from small, cryptic refugia. In this study of northern red oak, Quercus rubra L., the dominant representative

1) University of Notre Dame, Department of Biological Sciences, 327 Galvin Life Sciences, Notre Dame, IN 46556-5645.

2) Purdue University, Department of Entomology, West Lafayette, IN 47907.

*) Corresponding author: University of Notre Dame, Department of Biological Sciences, 327 Galvin Life Sciences, Notre Dame, IN 46556-5645, Fax: 574 6317413. E-mail: jromeros@nd.edu
\end{abstract}

of Quercus section Lobatae in the eastern United States, we address the question of appropriate sample size for accurate detection of the biogeographical distribution of chloroplast haplotype diversity in $Q$. rubra. We examined chloroplast DNA (cpDNA) variation in all $Q$. rubra over $17 \mathrm{~cm}$ in diameter (310 trees) in three forest fragments with documented histories of minimal disturbance for the last 100-190 years. cpDNA polymorphisms in three intergenic regions revealed different haplotype frequencies between the two local fragments located within $1 \mathrm{~km}$ of each other and complete discontinuity for the predominant haplotype between these two sites and a site $207 \mathrm{~km}$ distant. Haplotypes displayed positive spatial autocorrelation over 10-40 meter distances. Sample sizes of 10 or fewer taken at 50 meter intervals along a linear transect yielded poor estimates of haplotype frequencies and did not accurately detect haplotype richness.

Key words: cpDNA, Quercus rubra, chloroplast, genetic diversity, patch size, postglacial migration. 